\title{
Crude Glycerin and Energy Density of Diets for Growing, Pre-Lay and Pre-Peak Backcob Brown Egg-Laying Hens
}

-Author(s)

Avellaneda $Y^{\prime}$ (iD https://orcid.org/0000-0003-2471-5863 Ariza-Nieto Cl (D) https://orcid.org/0000-0001-9965-0625 Afanador-Téllez G" (iD https://orcid.org/0000-0002-1267-821X

AGROSAVIA, Corporación Colombiana de Investigación Agropecuaria, Bogota, Colombia. Universidad Nacional de Colombia, campus Bogotá, Colombia.

\section{-Mail Address}

Corresponding author e-mail address Yesid Avellaneda

Carrera 2 No. 24-02, Torre 5, Apartamento 318, Funza, Cundinamarca, 250020,

Colombia.

Phone: +57 3157932923

Email: yavellaneda@agrosavia.co

\section{- Keywords}

Feed intake, feed conversion, transitional diets, egg production.

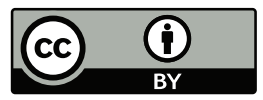

Submitted: 06/September/2019 Approved: 19/April/2020

\section{ABSTRACT}

A total of 32013 -weeks-old pullets were weighed and randomly allocated to treatments comprised by four levels of crude glycerin $(0$, 3,6 or $9 \%$ ) and two levels of ME (metabolizable energy, difference of $100 \mathrm{kcal} / \mathrm{kg}$ ) in the diets growing (14 to 17 weeks of age), pre-lay and pre-peak (low: 2750, 2800 and $2750 \mathrm{kcal} / \mathrm{kg}$ and high: 2850, 2900 and $2850 \mathrm{kcal} / \mathrm{kg}$, respectively). During the study, body weight was registered until 30 weeks of age, feed intake, egg weight and egg-production for each repetition and for individual hens were measured every week. The information was analyzed through a completely randomized design with a $4 \times 2$ factorial arrangement. During the growing phase, hens that received low energy diets consumed more feed $(p<0.05)$, gained less body weight $(p<0.05)$ and recorded lower feed conversion $(p<0.05)$. Besides, a positive linear effect $(p<0.05)$ was observed when including glycerin on feed conversion and weight gain. During the initial egglaying phase, hens fed low-energy diets consumed more feed $(p<0.05)$ and laid lighter eggs $(p<0.05)$. Furthermore, a positive linear effect $(p<0.05)$ of including crude glycerin on egg yield and feed intake was observed. After the egg-laying peak, the hens of high energy groups consumed $1.6 \mathrm{~g} / \mathrm{d}$ less feed $(p<0.05)$ and lay $0.9 \%$ less eggs, also, it a quadratic effect of inclusion of glycerin on laying-eggs was observed. In conclusion, the use of high energy diets decrease feed intake, increase egg weight until peak, but decrease the percentage of eggs post-peak; glycerin used in diets increases feed intake and improves egg-laying rate in different ways during the laying phase.

\section{INTRODUCTION}

Egg production in recent years has experienced a progressively rapid growth (Alexandratos \& Bruinsma, 2012) and a significant increase in consumption from $8.1 \mathrm{~kg}$ in the year 2000 to $8.9 \mathrm{~kg}$ in the year 2009 (FAOSTAT), up to an estimate of 8.9 and $13.8 \mathrm{~kg}$ in developing and industrialized countries by the year 2030, respectively (Bruisma, 2003). The previous situation means that bird feeding systems must be continuously updated since the profitability of the poultry sector is correlated with the price of the diet (Altahat et al., 2012). Thus, the design of feeding strategies that reduce production costs without altering the productive performance of current lines is a priority for the poultry sector.

In egg-laying hens, the period around the beginning of the egglaying phase constitutes a critical moment for the subsequent productive performance of the hen (Sujatha \& Rajini, 2015). Two to three weeks before laying the first egg, there is a significant increase in the weight gain of the egg-laying hens that seek to accumulate body reserves to support the production and size of the eggs during the egg-laying cycle (Summers, 1993). Besides, towards the end of the growth period, there 
is a rapid development of the ovary and the oviduct and an increase in the size of the liver (Sujatha et al., 2014). From the nutritional point of view, adequate contribution of energy and protein in the diet should be considered at this stage, as this will allow the correct accumulation of body reserves (Cankaya et al., 2008) and appetite stimulation in the animal, to increase its feed intake capacity (Leeson \& Summers, 2000; Lazaro \& Mateos, 2008).

The energy concentration of diets affects the productive performance of both growing chicks and egg-laying hens (Pérez-Bonilla et al., 2012; Saldaña et al., 2015). In general, it is widely recognized that energy is one of the main nutritional factors that control feed intake and contributes significantly to the cost of the diet (Classen, 2017). Studies suggest that birds consume to meet energy requirements (Fisher \& Wilson, 1974. The previous approach has been questioned, since certain strains of egg-laying hens fail to adjust their consumption, resulting in responses that are not uniform or predictable (Jalal et al., 2007; Classen, 2017), resulting in the limited ability to increase consumption when low energy diets are used (van Krimpen et al., 2007), a situation that could be revealed and affect economic return of a poultry company. This would occur if - due to the cost of raw materials - the production of low energy diets is implemented; thus, birds must sacrifice egg-laying or the size of the eggs due to the limited energy intake (de Persio et al., 2015). On the other hand, it is also necessary to economically assess the compensation in feed efficiency achieved by using high energy diets (Leeson \& Summers, 2009).

Glycerin production from the biodiesel industry reached more than 2 million tons in 2011 (Ciriminna et al., 2014), which has caused the price of this coproduct to decrease in the market (Yang et al., 2012) giving the possibility for its use as an alternative resource in animal feeding systems (Makkar, 2012; Silva et al., 2014; Beserra et al., 2016; Vongsamphanh et al., 2017). Glycerol, the main component of glycerin, is a molecule that has a rapid intestinal absorption (Kato et al., 2004), and due to the low caloric increaseit has a high net or effective energy value (AVINESP, 2014). In egg-laying hens this co-product has been used at levels of up to $15 \%$ for short periods (Lammers et al., 2008; Nemeth et al., 2013) or at $7.5 \%$ for several weeks in the egg-laying cycle (Boso et al., 2013; Cufadar et al., 2016).

Glycerin consumption during the transition stage (period around the beginning of the egg-laying phase, in this study from 14 weeks to $50 \%$ of laying-eggs) of laying-hens that receive low energy diets might stimulate feed consumption and improve growth during the last phase of the growth period and thus, improve production during egg-laying. This study aims to evaluate the effect of the inclusion of crude glycerin in diets with different metabolizable energy values during the growing (weeks 14 to 16), pre-lay (week 17 until reaching 5\% egg-laying) and pre-peak phases (from 5\% to $50 \%$ egg-laying) on the productive performance of Backcob Brown egg-laying hens until 40 weeks of age.

\section{MATERIAL AND METHODS}

This study was carried out in the Poultry Unit of the Cl Tibaitatá of the Colombian Agricultural Research Corporation, Agrosavia, located at 2516 masl (4.685222 -74.204722), with average temperature of $14{ }^{\circ} \mathrm{C}$ and a relative humidity of $76 \%$

\section{Experimental unit}

For this study, 320 chicks of the Backcob Brown line of 13 weeks of age were selected from a commercial lot and distributed according to their weight to comprise homogeneous experimental units. The birds were placed individually in two-level battery cages, each equipped with an automatic nipple drinker and a lateral channel feeder. Five chicks that shared the same feeder and were separated from the others were considered an experimental unit (eight per treatment).

\section{Experimental diets}

Animal management protocols were endorsed by the Bioethics Committee of the Faculty of Veterinary Medicine and Zootechnics, National University of Colombia, Bogotá(act 05). The glycerin used in this study was obtained from an oil-palm biodiesel production plant. The composition of the crude glycerin was as follows: $3547 \mathrm{kcal} / \mathrm{kg}$ of GE (Adiabatic Parr calorimetric pump), $8.21 \%$ humidity (Karl Fischer columbimetric titrator), $84.2 \%$ glycerol (gas chromatograph PERKIN ELMER), $4.52 \%$ ash, $1.73 \%$ sodium (PERKIN ELMER 2380 atomic absorption spectrophotometer) and 19.7 ppm of methanol (gas chromatograph PERKIN ELMER). For the formulation of diets a value of $3340 \mathrm{kcal}$ of $\mathrm{ME} / \mathrm{kg}$ was utilized for crude glycerin, which was obtained from its metabolicity (86\%) determinate in a previous balance bioassay carried out under similar conditions (Ariza et al., 2012). During each feeding phase, four levels of crude glycerin $(0,3,6$ and 9\%) 
and two levels of ME (low: with $2750 \mathrm{kcal}$ of ME/kg in growing and pre-peak, and $2800 \mathrm{kcal}$ in pre-laying; and high: with $2850 \mathrm{kcal}$ of $\mathrm{ME} / \mathrm{kg}$ in growing and pre-peak, and $2900 \mathrm{kcal}$ in pre-laying) were used in the diets. A phased feeding system was employed, where the growing phase was established from week 14 to week 16; the pre-laying phase from week 17 up to $5 \%$ of egg-laying; and the pre-peak phase from $5 \%$ to $50 \%$ egg-laying, per repetition.

Ingredients of diets was analyzed in analytical chemistry laboratory Agrosavia for gross energy
(Adiabatic Parr calorimetric pump), ethereal extract (Soxhlet methodology), nitrogen (Kjeldahl method), ash (calcination total), crude fiber (acid and alkaline hydrolysis). ME of each ingredient was calculated according to Rostagno et al., (2011). Details on the ingredients and the calculated nutritional profile of the different diets used in the study are presented in Tables 1, 2, and 3. Once each experimental repetition reached $50 \%$ of egg-laying, they began to receive feed for their production peak $(17.5 \%$ of CP and $3.8 \%$ of Ca) without glycerin, until 40 weeks of age.

Table 1 - Ingredients and nutritional composition of the experimental diets used from 14 to 17 week (g/kg on a fresh base).

\begin{tabular}{|c|c|c|c|c|c|c|c|c|}
\hline \multirow{2}{*}{ Ingredients } & \multicolumn{4}{|c|}{$2750 \mathrm{kcal}$ of ME/kg } & \multicolumn{4}{|c|}{$2850 \mathrm{kcal}$ of ME/kg } \\
\hline & $0 \%$ & $3 \%$ & $6 \%$ & $9 \%$ & $0 \%$ & $3 \%$ & $6 \%$ & $9 \%$ \\
\hline Corn & 483 & 442 & 408 & 370 & 448 & 416 & 383 & 350 \\
\hline Crude glycerin & 0 & 30 & 60 & 90 & 0 & 30 & 60 & 90 \\
\hline Wheat middlings & 170 & 170 & 170 & 170 & 170 & 170 & 170 & 170 \\
\hline Rice polishing & 120 & 120 & 120 & 120 & 120 & 120 & 120 & 120 \\
\hline Soybeans whole extruded & 0 & 0 & 0 & 0 & 60 & 60 & 60 & 60 \\
\hline Soybean meal 49 & 186 & 192 & 198 & 204 & 145 & 147 & 153 & 153 \\
\hline Fish meal & 0 & 0 & 0 & 0 & 1 & 4 & 2 & 5 \\
\hline Soybean oil & 3 & 6 & 6 & 8 & 15 & 15 & 15 & 15 \\
\hline Common salt & 3 & 3 & 3 & 3 & 3 & 3 & 3 & 3 \\
\hline Sodium bicarbonate & 3 & 5 & 3 & 3 & 4 & 3 & 3 & 3 \\
\hline Calcium carbonate & 10 & 9 & 9 & 9 & 9 & 9 & 9 & 9 \\
\hline Tricalcium phosphate & 10 & 11 & 11 & 12 & 10 & 10 & 11 & 10 \\
\hline DL-Methionine & 2 & 2 & 2 & 2 & 2 & 2 & 2 & 2 \\
\hline Choline chloride $60 \%$ & 7 & 7 & 7 & 7 & 7 & 7 & 7 & 7 \\
\hline Premix vit-min ${ }^{1}$ & 3 & 3 & 3 & 3 & 3 & 3 & 3 & 3 \\
\hline \multicolumn{9}{|l|}{ Calculated analysis } \\
\hline ME (kcal/kg) & 2750 & 2750 & 2750 & 2750 & 2850 & 2852 & 2850 & 2850 \\
\hline Crude protein (\%) & 16.5 & 16.5 & 16.5 & 16.5 & 16.6 & 16.7 & 16.5 & 16.5 \\
\hline $\mathrm{EE}(\%)^{2}$ & 3.4 & 3.4 & 3.4 & 3.5 & 5.4 & 5.4 & 5.3 & 5.3 \\
\hline $\mathrm{CF}(\%)^{3}$ & 4.8 & 4.8 & 4.8 & 4.7 & 4.9 & 4.9 & 4.8 & 4.8 \\
\hline Calcium (\%) & 0.90 & 0.90 & 0.90 & 0.90 & 0.88 & 0.89 & 0.90 & 0.90 \\
\hline Available P (\%) & 0.38 & 0.38 & 0.38 & 0.38 & 0.38 & 0.38 & 0.38 & 0.38 \\
\hline Digestible P (\%) & 0.43 & 0.43 & 0.44 & 0.44 & 0.42 & 0.42 & 0.43 & 0.43 \\
\hline DEB $(\mathrm{mEg} / \mathrm{kg})^{4}$ & 270 & 270 & 250 & 250 & 259 & 248 & 250 & 250 \\
\hline Digestible lysine (\%) & 0.72 & 0.73 & 0.74 & 0.74 & 0.73 & 0.76 & 0.74 & 0.75 \\
\hline Digestible Met+Cys (\%) & 0.59 & 0.59 & 0.60 & 0.60 & 0.59 & 0.63 & 0.60 & 0.63 \\
\hline Diet price (USD/kg) & 0.30 & 0.30 & 0.29 & 0.29 & 0.31 & 0.31 & 0.30 & 0.30 \\
\hline
\end{tabular}

${ }^{1}$ Premix of vitamins and minerals (contribution per kilogram of diet): vitamin A, $7500 \mathrm{IU}$; vitamin D3, 1,900 IU; vitamin E, $28 \mathrm{IU}$; vitamin K3, $1.5 \mathrm{mg}$; thiamine, $2.0 \mathrm{mg}$; riboflavin, 5.0 mg; niacin, 30 mg; pantothenic acid, 10 mg; pyridoxine, 2.8 mg; biotin, 0.01 mg; folic acid, 0.7 mg; vitamin B12, 0.01 mg; choline, 10 mg; Zn, 65 mg; Mn, 70 mg; Fe, 50 mg; Cu, 10 mg; I, $1.0 \mathrm{mg}$; and Se, $0.3 \mathrm{mg} .{ }^{2}$ Ethereal extract. ${ }^{3}$ Crude fiber. ${ }^{4}$ Dietary electrolyte balance. ${ }^{5}$ Digestible Methionine+Cysteine (\%).

\section{Experimental protocol}

Hens were weighed weekly until they reached an age of 24 weeks and then biweekly until they were 30 weeks of age, to establish weight gain. Besides, feed residuals were recorded weekly to calculate the average feed intake and feed conversion. During the egg-laying phase, the eggs of each repetition were collected daily and timely (11:00 hours), and at the end of the week, they were totaled, weighed and classified to calculate the feed conversion per dozen eggs and egg-laying percentage. Furthermore, the individual record of each hen was kept until reaching 40 weeks of age, in which at the beginning of the egglaying phase, the number of consecutive eggs laid, as well as the resting period between each brood, were counted. Finally, at 25 and 35 weeks of age, two AAsized eggs were selected for each repetition to assess shell thickness (Ames brand micrometer, model 25-5), 
Table 2 - Ingredients and nutritional composition of the experimental diets for the pre-laying phase ( $\mathrm{g} / \mathrm{kg}$ on a fresh base).

\begin{tabular}{|c|c|c|c|c|c|c|c|c|}
\hline \multirow{2}{*}{ Ingredients } & \multicolumn{4}{|c|}{$2800 \mathrm{kcal}$ of $\mathrm{ME} / \mathrm{kg}$} & \multicolumn{4}{|c|}{$2900 \mathrm{kcal}$ of ME/kg } \\
\hline & $0 \%$ & $3 \%$ & $6 \%$ & $9 \%$ & $0 \%$ & $3 \%$ & $6 \%$ & $9 \%$ \\
\hline Corn & 464 & 440 & 403 & 365 & 475 & 440 & 438 & 405 \\
\hline Crude glycerin & 0 & 30 & 60 & 90 & 0 & 30 & 60 & 90 \\
\hline Wheat middling & 190 & 190 & 190 & 190 & 170 & 169 & 139 & 135 \\
\hline Rice polishing & 25 & 0 & 0 & 0 & 0 & 5 & 0 & 0 \\
\hline Soybeans whole extruded & 100 & 100 & 100 & 100 & 130 & 130 & 125 & 125 \\
\hline Soybean meal 49 & 123 & 140 & 146 & 152 & 118 & 118 & 135 & 140 \\
\hline Fish meal & 10 & 10 & 10 & 10 & 10 & 10 & 10 & 10 \\
\hline Soybean oil & 12 & 15 & 16 & 18 & 22 & 22 & 17 & 18 \\
\hline Common salt & 3 & 3 & 3 & 3 & 3 & 3 & 3 & 3 \\
\hline Sodium bicarbonate & 4 & 3 & 3 & 3 & 4 & 6 & 4 & 4 \\
\hline Calcium carbonate & 51 & 51 & 50 & 50 & 51 & 50 & 51 & 51 \\
\hline Tricalcium phosphate & 10 & 11 & 12 & 12 & 11 & 10 & 11 & 11 \\
\hline DL-Methionine & 3 & 3 & 3 & 3 & 2 & 3 & 3 & 3 \\
\hline L-Lysine $\mathrm{HCl}$ & 1 & 0 & 0 & 0 & 0 & 0 & 0 & 0 \\
\hline L- Threonine & 1 & 0 & 1 & 1 & 0 & 1 & 1 & 1 \\
\hline Choline chloride $60 \%$ & 1 & 1 & 1 & 1 & 1 & 1 & 1 & 1 \\
\hline Premix vit-min ${ }^{1}$ & 3 & 3 & 3 & 3 & 3 & 3 & 3 & 3 \\
\hline \multicolumn{9}{|l|}{ Calculated analysis } \\
\hline ME (kcal/kg) & 2800 & 2800 & 2800 & 2800 & 2900 & 2900 & 2900 & 2900 \\
\hline Crude protein (\%) & 16.9 & 17.1 & 17.1 & 17.1 & 17.1 & 16.9 & 17.0 & 17.0 \\
\hline $\mathrm{EE}(\%)^{2}$ & 4.8 & 4.6 & 4.7 & 4.8 & 6.0 & 6.1 & 5.4 & 5.4 \\
\hline $\mathrm{CF}(\%)^{3}$ & 4.4 & 4.2 & 4.2 & 4.2 & 4.2 & 4.1 & 3.8 & 3.7 \\
\hline Calcium (\%) & 2.5 & 2.5 & 2.5 & 2.5 & 2.5 & 2.5 & 2.5 & 2.5 \\
\hline Available P (\%) & 0.40 & 0.40 & 0.40 & 0.40 & 0.40 & 0.40 & 0.41 & 0.40 \\
\hline Digestible P (\%) & 0.39 & 0.40 & 0.41 & 0.41 & 0.39 & 0.38 & 0.38 & 0.38 \\
\hline $\mathrm{DEB}(\mathrm{mEq} / \mathrm{kg})^{4}$ & 252 & 250 & 250 & 250 & 250 & 260 & 251 & 250 \\
\hline Digestible lysine (\%) & 0.80 & 0.79 & 0.79 & 0.79 & 0.77 & 0.79 & 0.80 & 0.82 \\
\hline Digestible Met+Cys (\%) ${ }^{5}$ & 0.73 & 0.71 & 0.71 & 0.72 & 0.70 & 0.72 & 0.73 & 0.75 \\
\hline Diet price (USD/kg) & 0.31 & 0.30 & 0.30 & 0.30 & 0.31 & 0.31 & 0.31 & 0.31 \\
\hline
\end{tabular}

${ }^{1}$ Premix of vitamins and minerals (contribution per kilogram of diet): vitamin A, $7500 \mathrm{IU}$; vitamin D3, $1900 \mathrm{IU}$; vitamin E, $28 \mathrm{IU}$; vitamin K3, $1.5 \mathrm{mg}$; thiamine, $2.0 \mathrm{mg}$; riboflavin, 5.0 mg; niacin, 30 mg; pantothenic acid, 10 mg; pyridoxine, 2.8 mg; biotin, 0.01 mg; folic acid, 0.7 mg; vitamin B12, 0.01 mg; choline, 10 mg; Zn, 65 mg; Mn, 70 mg; Fe, 50 mg; Cu, 10 mg; I, $1.0 \mathrm{mg}$; Se, $0.3 \mathrm{mg}$. ${ }^{2}$ Ethereal extract. ${ }^{3}$ Crude fiber. ${ }^{4}$ Dietary electrolyte balance. ${ }^{5}$ Digestible Methionine+Cysteine (\%).

yolk color (Roche scale) and the height of the albumin (Ames brand micrometer, model S-8400) in animal nutrition laboratory. Moreover, Haugh units $(100 * \log$ (albumin height $-1.7 *\left(\right.$ egg weight $\left.\left.{ }^{0.37}\right)+7.6\right)$ ) were calculated as an indicator of egg quality.

With the weekly results of feed conversion per dozen eggs for each repetition, and the price and the time the diets were used during the growing, prelaying and pre-peak phases, the feeding cost from week 20 to week 28 was calculated. Subsequently, with the price of the peak diet, the feeding cost from week 29 to week 40 was calculated. On the other hand, with the weekly distribution of eggs in the different categories, the calculation of the income per dozen eggs were made using the average sales prices in Colombia. With the above information, gross profitability was calculated as the difference between the income per dozen eggs and the cost of feed per dozen eggs.

\section{Statistical analysis}

Dates were grouped in the four following ranges: from 14 to 16 weeks, from 17 weeks to the beginning of laying and pre-peak and post-peak phase. Data were evaluated through a completely randomized design with a $4 \times 2$ factorial arrangement corresponding to four levels of glycerin (0,3, 6 and $9 \%)$ and two energy densities (low and high), using as a covariate in the design, the initial weight of each repetition. A test of adjusted means was used to assess the effect of the interaction, setting the glycerin level factor or energy density of the diet for the corresponding comparison. When the main effects were significant, Tukey's means test was performed comparing glycerin levels or energy density of the diets. Additionally, the type of effect (linear, quadratic, or cubic) of the glycerin inclusion in the diet was evaluated through contrasts. The information was processed using the $S A S \otimes$ statistical package version 9.2 (2008), with a mixed procedure. 
Table 3 - Ingredients and nutritional composition of the experimental diets for the pre-peak phase ( $\mathrm{g} / \mathrm{kg}$ on a fresh base).

\begin{tabular}{|c|c|c|c|c|c|c|c|c|}
\hline \multirow{2}{*}{ Ingredients } & \multicolumn{4}{|c|}{$2750 \mathrm{kcal}$ of $\mathrm{ME} / \mathrm{kg}$} & \multicolumn{4}{|c|}{$2850 \mathrm{kcal}$ of ME/kg } \\
\hline & $0 \%$ & $3 \%$ & $6 \%$ & $9 \%$ & $0 \%$ & $3 \%$ & $6 \%$ & $9 \%$ \\
\hline Corn & 460 & 401 & 364 & 327 & 423 & 389 & 357 & 323 \\
\hline Crude glycerin & 0 & 30 & 60 & 90 & 0 & 30 & 60 & 90 \\
\hline Wheat middling & 169 & 190 & 190 & 190 & 190 & 190 & 190 & 190 \\
\hline Soybeans whole extruded & 120 & 120 & 120 & 120 & 140 & 140 & 140 & 140 \\
\hline Soybean meal 49 & 138 & 141 & 147 & 152 & 99 & 111 & 108 & 109 \\
\hline Fish meal & 0 & 0 & 0 & 0 & 18 & 12 & 18 & 20 \\
\hline Soybean oil & 13 & 18 & 20 & 21 & 30 & 30 & 30 & 30 \\
\hline Common salt & 3 & 3 & 3 & 3 & 3 & 3 & 3 & 3 \\
\hline Sodium bicarbonate & 2 & 2 & 2 & 1 & 3 & 2 & 2 & 2 \\
\hline Calcium carbonate & 80 & 80 & 80 & 79 & 80 & 80 & 80 & 80 \\
\hline Tricalcium phosphate & 8 & 8 & 9 & 9 & 5 & 6 & 6 & 6 \\
\hline DL-Methionine & 3 & 3 & 3 & 3 & 3 & 3 & 3 & 3 \\
\hline L-Lysine $\mathrm{HCl}$ & 0 & 0 & 0 & 0 & 0 & 0 & 0 & 1 \\
\hline L- Threonine & 1 & 1 & 1 & 1 & 1 & 1 & 1 & 1 \\
\hline Choline chloride $60 \%$ & 1 & 1 & 1 & 1 & 1 & 1 & 1 & 1 \\
\hline Premix vit-min ${ }^{1}$ & 3 & 3 & 3 & 3 & 3 & 3 & 3 & 3 \\
\hline \multicolumn{9}{|l|}{ Calculated analysis } \\
\hline ME (kcal/kg) & 2750 & 2750 & 2750 & 2750 & 2850 & 2850 & 2850 & 2850 \\
\hline Crude protein (\%) & 17.0 & 17.0 & 17.0 & 17.0 & 17.0 & 17.0 & 17.0 & 17.0 \\
\hline $\mathrm{EE}(\%)^{2}$ & 4.8 & 5.3 & 5.4 & 5.5 & 7.0 & 6.9 & 6.9 & 6.8 \\
\hline $\mathrm{CF}(\%)^{3}$ & 4.1 & 4.2 & 4.2 & 4.2 & 4.2 & 4.2 & 4.1 & 4.0 \\
\hline Calcium (\%) & 3.5 & 3.5 & 3.5 & 3.5 & 3.5 & 3.5 & 3.5 & 3.5 \\
\hline Available P (\%) & 0.34 & 0.34 & 0.34 & 0.34 & 0.34 & 0.34 & 0.34 & 0.34 \\
\hline Digestible P (\%) & 0.33 & 0.35 & 0.35 & 0.35 & 0.31 & 0.32 & 0.32 & 0.32 \\
\hline DEB $(\mathrm{mEg} / \mathrm{kg})^{4}$ & 230 & 230 & 230 & 230 & 240 & 230 & 230 & 230 \\
\hline Digestible lysine (\%) & 0.78 & 0.78 & 0.79 & 0.80 & 0.78 & 0.79 & 0.80 & 0.82 \\
\hline Digestible Met+Cis $(\%)^{5}$ & 0.71 & 0.71 & 0.72 & 0.73 & 0.71 & 0.72 & 0.73 & 0.74 \\
\hline Diet price $(\$ / \mathrm{kg})$ & 0.31 & 0.31 & 0.31 & 0.30 & 0.32 & 0.31 & 0.31 & 0.31 \\
\hline
\end{tabular}

'Premix of vitamins and minerals (contribution per kilogram of diet): vitamin A, $7500 \mathrm{IU}$; vitamin D3, $2000 \mathrm{IU}$; vitamin E, $10 \mathrm{IU}$; vitamin K3, $1.8 \mathrm{mg}$; thiamine, $1.8 \mathrm{mg}$; riboflavin, 4.0 mg; niacin, 25 mg; pantothenic acid, 10 mg; pyridoxine, 1.7 mg; biotin, 0.1 mg; folic acid, 0.5 mg; vitamin B12, 0.01 mg; choline, 12 mg; Zn, 72 mg; Mn, 77 mg; Fe, 55 mg; Cu, 11 $\mathrm{mg} ; \mathrm{l}, 1.1 \mathrm{mg} ; \mathrm{Se}, 0.33 \mathrm{mg} .{ }^{2}$ Ethereal extract. ${ }^{3}$ Crude fiber. ${ }^{4}$ Dietary electrolyte balance. ${ }^{5}$ Digestible Methionine+Cysteine (\%)

To establish the effect of the experimental treatments on the parameters of the egg-laying curve, the data were adjusted to the McMillan model (1981), an equation that registered the best fit, given the evaluation time (40 weeks), and whose parameters explain the biological process (López, 2008). The equation used was the following:

$$
y \mathrm{t}=\mathrm{a}\left(\mathrm{e}^{-\mathrm{k1} * \mathrm{t}}-\mathrm{e}^{-\mathrm{k} 2^{\star} \mathrm{t}}\right)
$$

Where $y t$ is egg-laying at week $t$; $a$ is the asymptotic egg-laying value; $k 1$ is the rate of decrease in egg production after the egg-laying peak; $k 2$ is the instant rate of increase in egg production.

The data was processed using the NLIN procedure of the SAS statistical package. The test described by Motulsky \& Christopoulos (2003) was used to evaluate the existence of different egg-laying curves based on experimental treatments, using the error information of the reduced model (regardless of clustering) and the complete model (with different parameters for each group).

\section{RESULTS AND DISCUSSION}

In all the variables evaluated, no interaction was observed; therefore, the results are presented and discussed with the main effects. During the growing phase, i.e., from week 14 to 16 , a significant effect of the energy density of the diet on the response of the hens was observed (table 4). Birds that received low energy diets consumed more $(p<0.05)$ feed $(+1.6 \mathrm{~g} / \mathrm{d})$ but recorded a lower $(p<0.05)$ weight gain $(-0.4 \mathrm{~g} / \mathrm{d})$ and higher $(p<0.05)$ feed conversion $(+0.70 \mathrm{~g} / \mathrm{g})$. On the other hand, a linear effect $(p<0.05)$ of including crude glycerin in the diets was observed, where the higher the inclusion of this co-product, the higher the weight gain and the lower the feed conversion. Subsequently, from week 17 to 19, birds fed lowenergy diets consumed $2.6 \mathrm{~g} / \mathrm{d}$ more $(p<0.05)$ feed compared to those who received more energetic diets. Additionally, the hens that were fed diets containing $9 \%$ crude glycerin weighed $30 \mathrm{~g}$ more $(p=0.0806)$ compared to those in the control group. 
The productivity increase (weight gain and feed efficiency), observed during the growing phase (14 to 16 weeks of age) in pullets that received high energy diets can be associated with the higher inclusion of soybean oil (1.5 vs. $0.6 \%$ for high and low, respectively) and higher concentration of ethereal extract in the diets ( 5.4 vs. $3.4 \%$ for high and low, respectively). In this sense, birds fed high-fat diets have a higher feeding efficiency since they have a low caloric increase (Baiao \& Lara, 2005) and make the bolus retention rate higher, allowing a higher enzyme action time (Mateos \& Sell,
1981). On the other hand, Saldaña et al. (2015) report that the use of diets with different concentrations of metabolizable energy during the growth period did not affect the weight at 17 weeks of age, similar to what was observed in this study, since the birds managed to compensate the energy use through the increase in feed consumption. The previous results support the theory that birds, within a certain limit of energy concentration and/or diet presentation form, consume feed until they meet the energy requirement of their genetic potential (Leeson et al., 1996; Veldkamp et al., 2005).

Table 4 - Performance of Backcob Brown hens from 14 weeks to laying beginning fed low or high energy diets and crude glycerin.

\begin{tabular}{|c|c|c|c|c|c|c|c|}
\hline \multirow[b]{2}{*}{ Treatment } & \multicolumn{3}{|c|}{14 to 16 weeks } & \multicolumn{4}{|c|}{17 weeks until beginning laying } \\
\hline & $\begin{array}{l}\text { Weight gain } \\
(\mathrm{g} / \mathrm{d})\end{array}$ & $\begin{array}{c}\text { Feed intake } \\
(\mathrm{g} / \mathrm{d})\end{array}$ & $\begin{array}{c}\text { Feed conversion } \\
(\mathrm{g} / \mathrm{g})\end{array}$ & $\begin{array}{l}\text { Weight gain } \\
(\mathrm{g} / \mathrm{d})\end{array}$ & $\begin{array}{l}\text { Feed intake } \\
(\mathrm{g} / \mathrm{d})\end{array}$ & $\begin{array}{c}\text { Feed conversion } \\
(\mathrm{g} / \mathrm{g})\end{array}$ & $\begin{array}{c}\text { Weight at } \\
\text { week } 19(\mathrm{~g})\end{array}$ \\
\hline \multicolumn{8}{|l|}{$\mathrm{ME}$} \\
\hline High & $7.79 \mathrm{a}$ & $63.2 b$ & $8.23 \mathrm{a}$ & 13.4 & $81.9 b$ & 6.11 & 1.558 \\
\hline Low & $7.38 b$ & $64.8 \mathrm{a}$ & $8.95 b$ & 13.8 & $84.5 \mathrm{a}$ & 6.14 & 1.550 \\
\hline MSE $^{1}$ & 0.131 & 0.344 & 0.163 & 0.231 & 0.872 & 0.062 & 5.10 \\
\hline \multicolumn{8}{|l|}{ Glycerin } \\
\hline 0 & 7.34 & 63.6 & 8.82 & 13.2 & 82.3 & 6.26 & 1.536 \\
\hline 3 & 7.46 & 63.7 & 8.92 & 13.8 & 82.7 & 6.01 & 1.556 \\
\hline 6 & 7.66 & 64.2 & 8.46 & 13.6 & 83.7 & 6.18 & 1.557 \\
\hline 9 & 7.89 & 64.6 & 8.21 & 13.9 & 83.9 & 6.06 & 1.567 \\
\hline $\mathrm{MSE}^{2}$ & 0.180 & 0.486 & 0.231 & 0.327 & 1.233 & 0.088 & 7.22 \\
\hline \multicolumn{8}{|l|}{ Effects $^{3}$} \\
\hline $\mathrm{ME}$ & * & $\star *$ & * & NS & * & NS & NS \\
\hline Glycerin & NS & NS & NS & NS & NS & NS & + \\
\hline Glycerin contrast ${ }^{4}$ & $\mathrm{~L}$ & $\mathrm{~L}$ & $\mathrm{~L}$ & NS & NS & NS & $\mathrm{L}$ \\
\hline Initial weight & $\star \star 5$ & $\star 6$ & $\star * 7$ & NS & $\star 8$ & NS & $\star * 9$ \\
\hline
\end{tabular}

${ }^{1}$ mean standard error for energy, $\mathrm{n}=32$.

${ }^{2}$ mean standard error for glycerin, $n=16$.

${ }^{3}+: p<0.1,{ }^{*}: p<0.05,{ }^{*} *: p<0.001$, NS: not significant.

${ }^{4} \mathrm{~L}$ : linear.

${ }^{5} 16.7(1.46)-0.0083(0.0013)^{*}$ Initial weight, $R^{2}: 0.388$.

${ }^{6} 56.2(3.88)+0.0070(0.0035)^{*}$ Initial weight, $R^{2}: 0.06$.

${ }^{7}-5.15(1.90)-0.0124(0.0017)^{*}$ Initial weight, $R^{2}: 0.458$.

${ }^{8} 57.1(9.21)+0.023(0.0083)^{*}$ Initial weight, $R^{2}: 0.115$.

${ }^{9} 613.2(55.5)+0.848(0.049)^{*}$ Initial weight, $R^{2}: 0.823$

The use of glycerin in growing and pre-laying phases of hens has not been reported in the literature; however, the increase in feed intake based on the inclusion of glycerin in the diets was described by Guerra et al. (2011) in chickens during growing phase, a response that has been associated with the increase in diet palatability (Min et al., 2010) or the improvement in feed texture (Loreska et al., 2017). On the other hand, Sehu et al. (2012) report a positive effect of the inclusion of glycerin on weight gain during the broiler phase of chicks. The increase in weight gain related to the consumption of glycerin can be associated with the increase in the net energy supply of glycerin compared to that of corn (the effective energy/metabolizable energy ratio for glycerin is 1 , and 0.87 for corn) (AVINESP, 2014).

Birds fed with low metabolizable energy diets registered, from 20 to 28 weeks of age, $2.4 \mathrm{~g} / \mathrm{d}$ more $(p<0.05)$ of feed intake, laid eggs weighing $0.8 \mathrm{~g}$ less $(p<0.05)$ and recorded $0.03 \mathrm{~kg}$ per dozen eggs ( $p=0.072$ ) of feed conversion, compared to those who received high energy diets (table 5). Also, a linear trend of the inclusion of crude glycerin in the diets on the weight gain of birds during that same period was observed. In that sense, with higher inclusion of glycerin, there was less weight 
gain; however, for the egg-laying percentage and feed consumption, the linear trend was directly proportional to the inclusion of glycerin in the diet. Besides, birds fed diets containing 3\% glycerin laid more eggs, and these were heavier $(p<0.05)$ compared to those of egg-laying hens that received diets with $6 \%$ glycerin. Additionally, the weight at the beginning of the study, i.e., in birds of 13 weeks of age, affected $(p<0.05)$ the performance variables up to the egg-laying peak.

Van Krimpen et al. (2007) observed that birds that consumed diets diluted by $10 \%$ from week 18 to 26 ,

Table 5 - Performance until the egg-laying peak of Backcob Brown egg-laying hens fed during the transition phase with low or high energy diets and crude glycerin.

\begin{tabular}{|c|c|c|c|c|c|c|}
\hline Treatment & $\begin{array}{l}\text { Feed intake } \\
(\mathrm{g} / \mathrm{bird} / \mathrm{d})\end{array}$ & $\begin{array}{l}\text { Weight gain } \\
(\mathrm{g} / \mathrm{d})\end{array}$ & $\begin{array}{c}\text { Egg-laying } \\
(\%)\end{array}$ & $\begin{array}{l}\text { Egg weight } \\
\text { (g) }\end{array}$ & $\begin{array}{l}\text { Egg mass } \\
(\mathrm{g})\end{array}$ & $\begin{array}{l}\text { Feed conversion } \\
\text { (kg/dozen eggs) }\end{array}$ \\
\hline \multicolumn{7}{|l|}{$\overline{M E}$} \\
\hline High & $103.4 \mathrm{~b}$ & 2.6 & 78.4 & $54.2 \mathrm{a}$ & 42.5 & $1.58 \mathrm{a}$ \\
\hline Low & 105.8 a & 2.7 & 78.9 & $53.4 b$ & 42.1 & $1.61 \mathrm{~b}$ \\
\hline $\mathrm{MSE}^{1}$ & 0.379 & 0.198 & 0.456 & 0.240 & 0.343 & 0.009 \\
\hline \multicolumn{7}{|l|}{ Glycerin } \\
\hline 0 & $103.2 \mathrm{~b}$ & 3.0 & 77.6 & $53.8 \mathrm{ab}$ & 41.7 & 1.60 \\
\hline 3 & $104.9 a b$ & 2.6 & 79.1 & $53.3 b$ & 42.3 & 1.59 \\
\hline 6 & $104.9 a b$ & 2.7 & 78.1 & $54.6 \mathrm{a}$ & 42.7 & 1.60 \\
\hline 9 & $105.4 \mathrm{a}$ & 2.2 & 79.8 & $53.4 \mathrm{ab}$ & 42.7 & 1.58 \\
\hline $\mathrm{MSE}^{2}$ & 0.537 & 0.280 & 0.646 & 0.340 & 0.485 & 0.013 \\
\hline \multicolumn{7}{|l|}{ Effects $^{3}$} \\
\hline ME diet & $* *$ & NS & NS & * & NS & * \\
\hline Glycerin & * & NS & + & * & NS & NS \\
\hline Glycerin contrast ${ }^{4}$ & L & L & L & C & NS & NS \\
\hline Initial weight & $\star \star 5$ & NS & $\star \star 6$ & $\star * 7$ & $\star \star 8$ & $\star 9$ \\
\hline
\end{tabular}

${ }^{1}$ mean standard error for energy, $n=32$.

${ }^{2}$ mean standard error for glycerin, $n=16$.

${ }^{3}+: p<0.1,{ }^{*}: p<0.05,{ }^{* *}: p<0.001, \mathrm{NS}$ : not significant.

${ }^{4} \mathrm{C}$ : Cubic; L: linear.

${ }^{5} 85.3(4.78)+0.017(0.0043)^{*}$ Initial weight, $R^{2}: 0.209$.

${ }^{6} 52.2(4.96)+0.024(0.0044)^{*}$ Initial weight, $R^{2}: 0.315$.

${ }^{7} 42.8(2.76)+0.0098(0.0024) *$ Initial weight, $R^{2}: 0.203$

${ }^{8} 19.5(3.52)+0.020(0.0031)^{*}$ Initial weight, $R^{2}: 0.405$.

$91.84(0.10)-0.00021(0.00009)^{*}$ Initial weight, $R^{2}: 0.083$.

compensated by consuming $10 \%$ more feed, which resulted in similar nutrient intake, and therefore, the performance was not affected; these results are similar to the ones observed in this study. Further, when dePersio et al. (2014) evaluated the dilution of the diet of up to $15 \%$ in hens of the Hy-Line W-36 variety, they found that the birds compensated for feed consumption during the first evaluation period (until reaching 26 weeks of age). However, later, with a continuous supply of the diluted diets, the birds did not increase the consumption of feed, limiting the intake of nutrients and negatively affecting the percentage of egg-laying and egg weight.

In this study, a linear trend of glycerin consumption was observed on the weight of the birds before the start of the egg-laying phase, a trend that was maintained in terms of egg production up to the egg-laying peak. Saldaña et al. (2016) reported that hens that consumed crushed diets were heavier at week 17 of age, which meant that they started production earlier and lay, until the $22^{\text {nd }}$ week of age, more eggs that were larger compared to those birds that were lighter and were fed diets in flour form (milled). Besides, these researchers report that the weight gain was higher in lighter birds at the beginning of the egg-laying phase, which coincides with the trend observed in glycerin consumption. It is generally recognized that hens that are lighter at the beginning of egg-laying produce fewer eggs that are smaller compared to those hens that are heavier (Leeson et al., 1997; Perez-Bonilla et al., 2012).

Min et al. (2010) indicate that glycerin can stimulate feed consumption as it has a sweet taste. The increase in feed consumption in egg-laying hens by using glycerin in diets was reported by Fontinele et al. (2017) in red egg-layers of 90 weeks of age, with an estimated maximum of $6 \%$, and also by Suchy et al. (2012) with 4\% glycerol, when they replaced soybean oil with glycerin. Some authors mention that the 
sodium present in glycerin may limit feed consumption (Guerra et al., 2011), however, in this study, the use of crude glycerin with $1.1 \%$ sodium did not cause that effect. The increase in egg-laying by using glycerin in diets was reported by Fontinele et al. (2017) in brown chickens in the second egg-laying cycle, where birds fed diets containing $10 \%$ crude glycerin laid $6 \%$ more eggs compared to birds in the control group.

Boso et al. (2013) observed that egg production of laying hens increased linearly with the consumption of glycerin in a range that varied between 1.5 and $7.5 \%$ during the 16 weeks that egg-laying lasted, and this response is directly related to the increase in feed consumption. This last group of researchers also reported a quadratic response in egg weight, with an estimated minimum inclusion of $4.9 \%$ glycerin (Boso et al., 2013). However, Fontinele et al. (2017) reported a positive linear effect of the inclusion of glycerin in diets on egg mass in brown chickens associated with increased feed consumption. Increase in feed intake positively affects egg mass, as reported by Zheng et al. (2020), when the supply of diets in mash or pellet was evaluated.

Consumption of low or high energy diets from week 13 and up to $50 \%$ egg-laying affected feed intake and egg-laying in Backcob Brown egg-laying hens after the egg-laying peak (Table 6). The birds that received low-energy diets during the transition phase consumed $1.6 \mathrm{~g}$ more feed $(p<0.05)$ and laid $0.9 \%$ more eggs than their counterparts. Similar to what was observed before the egg-laying peak, the weight at 13 weeks of age positively affected $(p<0.05)$ the productive performance between the egg-laying peak and the moment when they reached 40 weeks of age.

Studies that evaluate the effect of the use of diets with different energy concentrations during the end of the growing phase and the beginning of the egg-laying phase on the subsequent performance of the egglaying hens were not found in the literature. However, in the work developed by Saldaña et al. (2016), the use of diets with different levels of metabolizable energy during the growth phase (1 to 17 weeks of age) of egg-laying hens, contrary to what was observed in this study, did not affect subsequent performance during the egg-laying phase in terms of feed consumption, production, egg weight, feed efficiency or weight gain.

There are no reports in the literature of the dragging effect of glycerin consumption during the transition period on the subsequent performance of egglaying hens. However, research evaluating glycerin consumption on the productive response of egg- laying hens concludes, in accordance with what was found after the egg-laying peak, that the use of this co-product in diets does not affect feed consumption, not even when it is included in the formulation of diets (Swiatkiewicz \& Koreleski, 2009; Boso et al., 2013; Mandalawi et al., 2015) or when it is used to replace oil in the formulation (Cufadar et al., 2016; Kanbur et al., 2017). The previous result has also been found in egglaying quails (Erol et al., 2009; Ghayas et al., 2017).

Similarly, the use of this resource does not affect the percentage of egg-laying or the weight of an egg of egg-laying hens, when inclusions are lower than 7.5\% (Swiatkiewicz \& Koreleski, 2009; Yalcin et al., 2010; Duarte et al., 2014, Mandalawi et al., 2015) or when up to $75 \%$ of the energy contribution of oils is replaced by glycerin (Cufadar et al., 2016; Kanbur et al., 2017). In egg-laying quails, the use of diets with inclusions of up to $10 \%$ glycerin did not affect the percentage of egg-laying or egg weight (Erol et al., 2009; Ghayas et al., 2017). Some authors conclude that feed use efficiency in egg-laying hens is not affected by the inclusion of glycerin in the diets, since in some cases, the increase in egg-laying and mass was correlated with feed consumption (Fontinele et al., 2017) or a similar productive response is evidenced in the variables that build this index (Swiatkiewicz \& Koreleski, 2009).

The distribution of eggs in different categories was not affected by the experimental treatments (results by treatments no presented). The average of all treatments during the study was: Jumbo: $2.7 \%$, AAA: $23.8 \%$, AA: $30.1 \%$, A: $18.2 \%$, B: $16.4 \%, C$ : $8.5 \%$ and broken eggs: $0.8 \%$. Similarly, the physical characteristics of the eggs were not affected by the experimental treatments (results not presented), which on average, recorded the following values: $0.41 \mathrm{~mm}$ in shell thickness, 11.9 in color score, $5.95 \mathrm{~mm}$ in albumin height and 89.3 Haugh units. Similar to what was found in this study, the literature concludes that shell thickness, yolk color or the height of the albumin of the eggs are not affected by the levels of glycerin inclusion in the diets (Swiatkiewicz \& Koreleski, 2009 Boso et al., 2013; Duarte et al., 2014; Mandalawi et al., 2015; Cufadar et al., 2016; Fontinele et al., 2017).

The use of diets with different levels of metabolizable energy affected the shape of the egg-laying curve of egg layers (Table 7). Diets that contained less metabolizable energy had a lower rate of decline after the egg-laying peak and a higher $(p<0.05)$ rate of increase to the peak, a parameter that was also affected by the inclusion of crude glycerin in the diets. The estimation of the performance of an egg-laying 
Table 6 - Performance after the egg-laying peak and until 40 weeks of age in Backcob Brown egg layers fed during the transition phase with low or high energy diets and crude glycerin.

\begin{tabular}{|c|c|c|c|c|c|}
\hline Treatment & Feed intake (g/bird/d) & Egg laying (\%) & Egg weight (g) & Egg mass (g) & Feed conversion (kg/dozen) \\
\hline \multicolumn{6}{|l|}{$\mathrm{ME}$} \\
\hline High & $113.3 b$ & $96.1 \mathrm{~b}$ & 60.5 & 58.2 & 1.41 \\
\hline Low & $115.0 \mathrm{a}$ & $97.0 \mathrm{a}$ & 60.5 & 58.7 & 1.42 \\
\hline MSE$^{1}$ & 0.185 & 0.265 & 0.272 & 0.331 & 0.004 \\
\hline \multicolumn{6}{|l|}{ Glycerin } \\
\hline 0 & 114.0 & 95.8 & 60.9 & 58.4 & 1.43 \\
\hline 3 & 114.3 & 96.8 & 60.2 & 58.3 & 1.42 \\
\hline 6 & 114.0 & 97.0 & 60.7 & 58.9 & 1.42 \\
\hline 9 & 114.5 & 95.8 & 60.0 & 58.1 & 1.41 \\
\hline $\mathrm{MSE}^{2}$ & 0.262 & 0.375 & 0.385 & 0.469 & 0.005 \\
\hline \multicolumn{6}{|l|}{ Effects $^{3}$} \\
\hline ME diet & ** & * & NS & NS & NS \\
\hline Glycerin & NS & NS & NS & NS & NS \\
\hline Glycerin contrast ${ }^{4}$ & NS & $Q_{1}+$ & $\mathrm{L}$ & NS & NS \\
\hline Initial weight & $\star \star 5$ & $\star \star 6$ & $\star * 7$ & $\star \star 8$ & NS \\
\hline
\end{tabular}

${ }^{1}$ mean standard error for energy, $n=32$.

${ }^{2}$ mean standard error for glycerin, $\mathrm{n}=16$.

${ }^{3}+: p<0.1,{ }^{*}: p<0.05,{ }^{* *}: p<0.001$, NS: not significant.

${ }^{4}$ L: linear, Q: quadratic

${ }^{5} 103.0(2.86)+0.0092(0.0025)^{*}$ Initial weight, $R^{2}: 0.171$.

${ }^{6} 85.8(2.96)+0.0096(0.0026)^{*}$ Initial weight, $R^{2}: 0.173$.

${ }^{7} 47.5(2.83)+0.011(0.0025)^{*}$ Initial weight, $R^{2}: 0.228$.

$839.4(3.49)+0.016(0.0031)^{*}$ Initial weight, $R^{2}: 0.304$.

cycle (until week 72 of age) through the parameters of the McMillan model indicate that birds fed low-energy diets would produce 20 eggs more compared to those fed high-energy diets (330 and 310 for low and high energy, respectively). In the same way, birds fed diets during the transition period with $9 \%$ glycerin would produce about 10 more eggs compared to those in the control group $(326,333,335$ and 336 eggs per bird for diets with 0, 3, 6 and $9 \%$ glycerin, respectively).

Table 7 - Parameters of the egg-laying dynamics of Backcob Brown egg-laying hens fed during the transition phase with low and high energy and crude glycerin diets.

\begin{tabular}{lccc}
\hline \multirow{2}{*}{ Treatment } & \multicolumn{3}{c}{$\begin{array}{c}\text { Egg-laying curve parameters } \\
k 1^{2}\end{array}$} \\
\hline ME & $\mathrm{a}^{1}$ & & $\mathrm{k} 2^{3}$ \\
High & 99.2 & $0.0015 \mathrm{a}$ & $0.746 \mathrm{a}$ \\
Low & 102.1 & $0.0043 \mathrm{~b}$ & $0.663 \mathrm{~b}$ \\
\hline Glycerin & & & \\
\hline 0 & 101.2 & 0.0038 & $0.667 \mathrm{~b}$ \\
3 & 101.2 & 0.0030 & $0.662 \mathrm{~b}$ \\
6 & 100.0 & 0.0024 & $0.720 \mathrm{ab}$ \\
9 & 99.8 & 0.0023 & $0.774 \mathrm{a}$ \\
\hline
\end{tabular}

${ }^{1}$ Asymptotic egg-laying value, ${ }^{2}$ Rate of decrease in egg production after the egg-laying peak, ${ }^{3}$ Rate of increase in egg production until the egg-laying peak.

Otwinowska-Mindur et al. (2016) found that the egg-laying curve of hens with low productivity was characterized by a higher value of the rates of ascent to the peak and fall after the peak. In this study, layinghens with lower production recorded a lower rate of ascent to the peak, but a higher rate of descent. On the other hand, when the egg-laying curves of selected and unselected leghorn hens were compared, the authors found that the genetic improvement changed the pattern of the curve, mainly increasing the maximum potential parameter (a) and decreasing the rate of ascent to the peak (c) in the McMillan model (Savegnago et al., 2012).

Reproductive performance (characteristics of clutches and resting periods) up to the egg-laying peak was not affected ( $p>0.05$ ) by the energy density of the diet or the level of inclusion of crude glycerin (data not shown), given the high variation between individuals in the period evaluated. Furthermore, only the start of the egg-laying phase and the number of eggs accumulated up to the peak were affected $(p<0.05)$, due to the weight of the hens at 13 weeks of age. Until 40 weeks of age, egg-laying hens fed low energy diets recorded a higher $(p<0.05)$ number of eggs accumulated, a larger $(p<0.05)$ maximum brood size and also a higher $(p=0.061)$ average brood, compared to those who received diets with more energy (table 8). 
Table 8 - Characteristics of broods and resting periods until 40 weeks of age in Backcob Brown egg-laying hens fed during the transition phase with low or high energy diets and crude glycerin.

\begin{tabular}{|c|c|c|c|c|c|c|c|}
\hline Treatment & $\begin{array}{l}\text { Start of egg- } \\
\text { laying phase (s) }\end{array}$ & Eggs & Maximum broods (eggs) & Broods (eggs) & $\begin{array}{l}\text { No. of } \\
\text { broods }\end{array}$ & $\begin{array}{l}\text { Resting } \\
\text { period (d) }\end{array}$ & $\begin{array}{l}\text { No. of resting } \\
\text { periods }\end{array}$ \\
\hline \multicolumn{8}{|l|}{ ME } \\
\hline high & 20.2 & $130.1 \mathrm{a}$ & $71.3 b$ & 28.7 & 4.8 & 1.54 & 4.3 \\
\hline Low & 20.4 & $131.1 \mathrm{~b}$ & $81.5 \mathrm{a}$ & 34.7 & 4.1 & 1.58 & 3.9 \\
\hline $\mathrm{MSE}^{1}$ & 0.090 & 0.413 & 3.39 & 2.42 & 0.314 & 0.116 & 0.373 \\
\hline \multicolumn{8}{|l|}{ Glycerin } \\
\hline 0 & 20.4 & 129.3 & 75.6 & 30.0 & 4.7 & 1.66 & 4.0 \\
\hline 3 & 20.5 & 130.6 & 77.8 & 30.6 & 4.6 & 1.62 & 4.0 \\
\hline 6 & 20.2 & 131.1 & 81.5 & 32.3 & 4.4 & 1.48 & 4.1 \\
\hline 9 & 20.2 & 131.4 & 70.6 & 32.3 & 4.4 & 1.46 & 4.2 \\
\hline $\mathrm{MSE}^{2}$ & 0.128 & 0.584 & 4.80 & 3.42 & 0.445 & 0.164 & 0.528 \\
\hline \multicolumn{8}{|l|}{ Effects $^{3}$} \\
\hline ME diet & NS & * & * & + & NS & NS & NS \\
\hline Glycerin & + & + & NS & NS & NS & NS & NS \\
\hline Contrast glycerin ${ }^{4}$ & L & L & NS & NS & NS & NS & NS \\
\hline Initial weight & $\star 5$ & $\star \star 6$ & $\star 7$ & $\star 8$ & $* * 9$ & NS & $\star 10$ \\
\hline
\end{tabular}

${ }^{1}$ mean standard error for energy, $n=32$.

${ }^{2}$ mean standard error for glycerin, $\mathrm{n}=16$.

${ }^{3}+: p<0.1,{ }^{*}: p<0.05,{ }^{* *}: p<0.001$, NS: not significant.

${ }^{4} \mathrm{~L}$ : lineal.

${ }^{5} 22.5(0.98)-0.002(0.0009)^{*}$ Initial weight, $R^{2}: 0.076$.

${ }^{6} 103.9(4.65)+0.024(0.0041)^{*}$ Initial weight, $R^{2}: 0.346$.

$7-46.4(37.9)+0.110(0.034)^{*}$ Initial weight, $R^{2}: 0.144$.

${ }^{8}-51.9(25.3)+0.075(0.023)^{*}$ Initial weight, $R^{2}: 0.150$.

${ }^{9} 16.6(3.42)-0.010(0.0030)^{*}$ Initial weight, $R^{2}: 0.159$.

${ }^{10} 12.8(3.80)-0.0076(0.0034)^{\star}$ Initial weight, $R^{2}: 0.075$.

On the other hand, a linear trend of the inclusion of glycerin in diets with time was found at the beginning of the egg-laying phase, being lower $(p=0.068)$ in birds that consumed diets with more glycerin in the transition phase, a difference that translates in 2.1 days less when laying the first egg. In addition, birds fed diets without glycerin laid 2.1 eggs $(p=0.076)$ less compared to those in the treatment with $9 \%$ glycerin. An increase in body weight at 13 weeks of age resulted in less time at the beginning of the egg-laying phase, a higher number of cumulated eggs, larger broods, and fewer resting periods.

In egg-laying hens, the expression of the genetic potential related to productive efficiency and the degree of adaptation is associated with large brood sizes (Zerjal et al., 2013; Samiullah et al., 2016). The amount of eggs accumulated is a function of the broods and resting periods recorded by the egg-layers; in that sense, Erensayin \& Camci (2003) found that the correlation of this variable with the number of broods is negative, a response that was also observed in this study $(-0.408, p<0.001)$. In addition, a negative correlation was found between the amount of eggs accumulated and the length of the resting period
$(-0.459, p<0.01)$, which evidences the impact of the duration of this last on the performance of the birds, being similar to the results reported in the literature (Mutayoba et al., 2012; Alkan et al., 2013). On the other hand, early onset of egg-laying positively relates the number of total eggs per bird (Alkan et al., 2013), a ratio that was also found in this study $(-0.394 p<0.05)$.

Furthermore, egg-laying hens that were fed during the transition phase with high energy diets recorded a lower $(p<0.05)$ feeding cost to the egg-laying peak, compared to those that received low energy diets, which affected ( $p=0.0976)$ positively the gross profitability of that group of birds. On the other hand, chickens that received diets with 6 or $9 \%$ crude glycerin received $\$$ 89 more $(p=0.0981)$ per dozen eggs than birds fed 0 or $3 \%$ crude glycerin (table 9 ).

After the production peak, the economic evaluation was not affected by the experimental treatments. On the other hand, the weight of the chicks at 13 weeks of age significantly affected the economic indicators evaluated. In that sense, the higher the weight at that age, the higher the gross profitability associated mainly with an increase in income. Granghelli et al., (2019) and dePersio et al. (2015) observed that cost increased 
Table 9 - Economic evaluation of the feed of Backcob Brown egg-laying hens fed during the transition phase with low or high energy diets and crude glycerin (USD/dozen eggs).

\begin{tabular}{|c|c|c|c|c|c|c|}
\hline \multirow{2}{*}{ Treatments } & \multicolumn{3}{|c|}{ Until egg-laying peak } & \multicolumn{3}{|c|}{ From egg-laying peak until week 40} \\
\hline & Income & Feed cost & Income-cost & Income & Feed cost & Income-cost \\
\hline \multicolumn{7}{|l|}{$\mathrm{ME}$} \\
\hline high & 0.78 & $0.51 \mathrm{a}$ & 0.28 & 0.92 & 0.45 & 0.47 \\
\hline Low & 0.78 & $0.52 b$ & 0.26 & 0.92 & 0.46 & 0.46 \\
\hline $\mathrm{MSE}^{1}$ & 0.006 & 0.003 & 0.006 & 0.004 & 0.001 & 0.005 \\
\hline \multicolumn{7}{|l|}{ Glycerin } \\
\hline 0 & 0.77 & 0.51 & 0.25 & 0.92 & 0.46 & 0.46 \\
\hline 3 & 0.77 & 0.51 & 0.26 & 0.92 & 0.45 & 0.47 \\
\hline 6 & 0.79 & 0.52 & 0.28 & 0.92 & 0.45 & 0.47 \\
\hline 9 & 0.79 & 0.51 & 0.28 & 0.92 & 0.45 & 0.46 \\
\hline $\mathrm{MSE}^{2}$ & 0.009 & 0.005 & 0.009 & 0.006 & 0.002 & 0.007 \\
\hline \multicolumn{7}{|l|}{ Effects $^{3}$} \\
\hline ME diet & NS & * & + & NS & NS & NS \\
\hline Glycerin & + & NS & NS & NS & NS & NS \\
\hline Contrast glycerin ${ }^{4}$ & C & NS & $L$ & NS & NS & NS \\
\hline Initial weight & $\star \star 5$ & $\star 6$ & $* * 7$ & $\star 8$ & NS & $\star 9$ \\
\hline
\end{tabular}

1 mean standard error for energy, $n=32$.

${ }^{2}$ mean standard error for glycerin, $\mathrm{n}=16$.

${ }^{3}+: p<0.1,{ }^{*}: p<0.05,{ }^{* *}: p<0.001$, NS: not significant.

${ }^{4} \mathrm{C}$ : Cubic; L: linear.

${ }^{5} 1776.9(228.8)+0.846(0.205)^{*}$ Initial weight, $R^{2}: 0.214$.

${ }^{6} 2050.7(114.8)-0.244(0.103)^{*}$ Initial weight, $R^{2}: 0.083$.

${ }^{7}-273.7(227.7)+1.091(0.204)^{*}$ Initial weight, $R^{2}: 0.313$.

${ }^{8} 2769.9(147.3)+0.383(0.132)^{*}$ Initial weight, $R^{2}: 0.118$.

${ }^{9} 1114.7(158.7)+0.450(0.142)^{*}$ Initial weight, $R^{2}: 0.138$.

linearly with energy density of the diet, while gross profitability decreased. This is a response that contrasts with the results obtained in this study until week 28 since the use of diets with higher energy resulted in lower feed consumption, which reduced costs and increased profitability. In this study, glycerin inclusion in diets of transition phase of laying hens did not affect the costs, however, Pasquetti et al. (2014), observed a linear reduction in quail production costs with the use of crude glycerin, while Batista et al. (2013) and Avellaneda et al. (2018), found that the inclusion of refined glycerin negatively affects production costs.

In conclusion, laying-hens that received high energy diets during transition phase reduced feed intake during the overall assay, that reduces partial cost; besides, they lay heavier eggs in period from beginning laying to egg-laying peak and in less percentage after the egg-laying peak. A positive linear effect of glycerin consumption on weight gain and feed intake was observed from 14 to 17 weeks of age and during the pre-peak phase; also, the laying-egg rate was affected of linear form before laying-peak (higher percentage of eggs to higher inclusion of glycerin) and quadratic form after laying-peak (higher posture estimate around of $4.5 \%$ of glycerin inclusion) by glycerin intake.

\section{REFERENCES}

Alexandratos N, Bruisma J. World agriculture towards 2030/2050, the 2012 revision [ESA working paper, 12-03]. Rome: FAO; 2012.

Alkan S, Karsli T, Karabağ K, Galiç A. The effects of selection and season on clutch traits and egg production in japanese quails (Coturnix coturnix japonica) of different lines. Süleyman Demirel Üniversitesi Ziraat Fakültesi Dergisi 2013;8(1):71-77.

Altahat E, AL-Sharafat A, Altarawneh M. Factors affecting profitability of layer hens enterprises. American Journal of Agricultural and Biological Sciences 2012;7(1):106-113.

Ariza C, Afanador G, Avellaneda Y, Mejía G, Mayorga O, García G, et al. Glicerina y subproductos del biodiesel, alternativa energética para alimentación de aves y cerdos. Bogotá: Simbiosis, Ciencia y Publicidad; 2012.

AVINESP. Modelo de predição de crescimento e exigências nutricionais [Software]. Jaboticabal: FCAV/UNESP; 2014.

Baião N, Lara L. Oils and fat in broiler nutrition. Brazilian Journal of Poultry Science 2005;7(3):129-141.

Batista E, Furlan AC, Ton APS, Pasquetti TJ, Quadros TCO, Grieser DO, et al Avaliação nutricional da glicerina vegetal semipurificada para codornas de corte. Arquivo Brasileiro de Medicina Veterinária e Zootecnia 2013;65(6):783-1791

Beserra VA, Cesar AS, Peres AA. Adoção da glicerina bruta na dieta animal e seu impacto no produto final. Archivos de Zootecnia 2016;65(250):259-266.

Boso KMO, Mukarami CRA, Nascimento GR, Matumoto-Pintro PT, OspiaRojas IC. Fatty acid profile, performance and quality of eggs from laying hens fed with crude vegetable glycerine. International Journal of Poultry Science 2013;12(6):341-347. 
Bruisma J. World agriculture towards 2015/2030, an FAO perspective. London: Earthscan Publications; 2003.

Cankaya C, Ocak N, Sungu M. Canonical correlation analysis for estimation of relationships between sexual maturity and egg production traits upon availability of nutrients in pullets. Asian-Australian Journal of Animal Science 2008;21(11):1576-1584

Ciriminna R, Della Pina C, Rossi M, Pagliaro M. Understanding the glycerol market. European Journal of Lipid Science and Technology 2014;116(10):1-8

Classen H. Diet energy and feed intake in chickens. Animal Feed Science and Technology 2017;233:13-21.

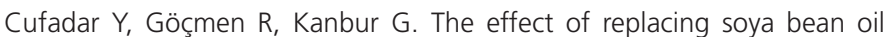
with glycerol in diets on performance, egg quality and egg fatty acid composition in laying hens. Animal 2016;10(1):19-24.

DePersio S, Utterback PL, Utterback CW, Rochell SJ, Sullivan NO, Bregendahl $\mathrm{K}$, et al. Effects of feeding diets varying in energy and nutrient density to Hy-Line W-36 laying hens on production performance and economics. Poultry Science 2015;94:195-206.

Duarte CRA, Mukarami AE, Boso KMO, Eyng C, Ospina-Rojas IC, MatumotoPintro PT. Mixed crude glycerin in laying hen diets:live performance and egg quality and fatty acid profile. Brazilian Journal of Poultry Science 2014;16(4):351-358.

Erensayin C, Camci O. Effect of clutch size on egg production in Japanese quails. Archiv für Geflugelkunde 2003;67(1):38-41.

Erol H, Yalçin S, Midilli M, Yalçin S. The effects of dietary glycerol on growth and laying performance, egg traits and some blood biochemical parameters in quails. Revue de Médecine Vétérinaire 2009;160(10):469476.

FAOSTAT. FAO statistical database. Rome; 2009. Available from: http:// faostat.fao.org/default.aspx.

Fisher C, Wilson BJ. Response to dietary energy concentration by growing chickens. In: Morris TR, Freeman BM, editors. Energy requirements of poultry. Edinburgh: British Poultry Science; 1974. p.151-184.

Fontinele GSP, Leite SCB, Cordeiro CN, Goulart C, Costa, AC, Neves JO, et al. Glycerin from biodiesel in the feeding of red-egg layers. Ciências Agrárias 2017;38(2):1009-1016.

Ghayas A, Hussain J, Mahmud A, Javed K, Rehman A, Ahmad S, et al. Productive performance, egg quality, and hatching traits of Japanese quail reared under different levels of glycerin. Poultry Science 2017:96:2226-2232

Granghelli CA, Burbarelli MFC, Lelis KD, Pelissari PH, Utimi NBP, Leite BGS, et al. Effects of dietary metabolizable energy levels and beak trimming on the performance, egg quality, and economic viability of layers. Poultry Science 2019;98:5831-5839.

Guerra RL, Murakami AE, Garcia AFQM, Urgnani FJ, Moreira I, Picoli KP. Glicerina bruta mista na alimentação de frangos de corte (1 a 42 dias). Revista Brasileira de Saúde e Produção Animal 2011;12(4):1038-1050.

Jalal MA, Scheideler SE, Pierson EM. Strain response of laying hens to varying dietary energy levels with and without Avizyme supplementation. Journal of Applied Poultry Research 2007;16:289-295.

Kanbur G, Cufadar Y, Göçmen R, Ünver A. Effects of dietary supplementation of glycerol on performance, egg quality and egg yolk fatty acid composition in laying hens. Eurasian Journal of Feed Science and Technology 2017;1(2):4-10.

Kato T, Hayashi Y, Inoue K, Yuasa H. Function characterization of the carriermediated transport system for glycerol in everted sacs of the rat small intestine. Biological Pharmacology Bulletin 2004;27(11):1826-1830.
Lammers PJ, Kerr BJ, Honeyman MS, Stalder KJ, Dozier III WA, Weber TE, et al. Nitrogen-corrected apparent metabolizable energy value of crude glycerol for laying hens. Poultry Science 2008;87:104-107.

Lázaro R, Mateus GG. Necesidades nutricionales para avicultura: pollos de carne y aves de postura. Madrid: FEDNA; 2008.

Leeson S, Caston L, Summers JD. Broiler response to diet energy. Poultry Science 1996;75:529-535.

Leeson S, Caston L, Summers JD. Layer performance of four strains of leghorn pullets subjected to various rearing programs. Poultry Science 1997;76:1-5

Leeson S, Summers JD. Feeding systems for poultry. In: Theodorou MK, France J, editors. Feeding systems and feed evaluation models. London: CABI Publishing; 2000. p. 211-237.

Leeson S, Summers JD. Commercial poultry nutrition. $3^{\text {rd }}$ ed. Nottingham: Nottingham University Press; 2009.

Lokesha E, Marappan G, Ramasamy DK, Brijesh P, Banakar PS, Revanasiddu $D$, et al. Crude glycerol:by-product of biodiesel industries as an alternative energy source for livestock feeding. Journal of Experimental Biology and Agricultural Sciences 2017;5(6):755-766.

Lopez S. Non-linear functions in animal nutrition. In: France J, Kebreab $\mathrm{E}_{\mathrm{B}}$ editors. Mathematical modelling in animal nutrition. London: $C A B$; 2008.

Makkar H. Biofuel co-products as livestock feed - opportunities and challenges. Rome: FAO; 2012

Mandalawi HA, Lázaro R, Redón M, Herrera J, Menoyo D, Mateos GG Glycerin and lecithin inclusion in diets for Brown egg-laying hens: effects on egg production and nutrient digestibility. Animal Feed Science and Technology 2015;209:145-56.

Mateos GG, Sell JL. Metabolizable energy of supplemental fat as related to dietary fat level and method of estimation. Poultry Science 1981;60:1509-1515.

McMillan I. Compartmental model analysis of poultry egg production curve. Poultry Science 1981;60:1549-1551.

Min YN, Yan F, Liu FZ, Coto C, Waldrop PW. Glycerin-A new energy source for poultry. International of Poultry Science 2010;9(1):1-4.

Motulsky H, Christopoulos A. Fitting models to biological data using linear and nonlinear regression. A practical guide to curve fitting. San Diego: GraphPad Software; 2003.

Mutayoba SK, Katule AK, Minga U, Mtambo MM, Olsen J E. The effect of supplementation on the performance of free-range local chickens in Tanzania. Livestock Research for Rural Development 2012;24:93.

Nemeth K, Zsedely E, Schmidt J. Nitrogen-corrected apparent metabolizable energy value of crude glycerol for laying hens. Annals of Animal Science 2013;13(4):829-836

Otwinowska-Mindur A, Gumułka M, Kania-Gierdziewicz J. Mathematical models for egg production in broiler breeder hens. Annals of Animal Science 2016;16(4):1185-1198.

Pasquetti TJ, Furlan AC, Martins EN, Ton APS, Batista E, Pozza PC, et al. Glicerina bruta para codornas de corte, de um a 14 e de 15 a 35 dias de idade. Arquivo Brasileiro de Medicina Veterinária e Zootecnia 2014;66 (5):1547-1556.

Pérez-Bonilla A, Novoa S, García J, Mohiti-Asli M, Frikha M, Mateos GG. Effects of energy concentration of the diet on productive performance and egg quality of brown egg-laying hens differing in initial body weight. Poultry Science 2012;91:3156-3166. 
Rostagno HS, Albino LFT, Donzele JL, Gomes PC, Oliveira RF, Lopes DC, et al. Tabelas brasileiras para aves e suínos - composição de alimentos e exigências nutricionais. $3^{a}$ ed. Viçosa: UFV; 2011.

Saldaña B, Guzmán P, Cámara L, García J, Mateos GG. Feed form and energy concentration of the diet affect productive performance and digestive tract traits of brown-egg laying pullets from hatching to 17 weeks of age. Poultry Science 2015;94:1879-1893.

Saldaña B, Gewehra CE, Guzmán P, García J, Mateos GG. Influence of feed form and energy concentration of the rearing phase diets on productivity, digestive tract development and body measurements of brown-egg laying hens fed diets varying in energy concentration from 17 to 46wk of age. Animal Feed Science and Technology 2016;221:87100.

Samiullah S, Roberts J, Chousalkar K. Oviposition time, flock age, and egg position in clutch in relation to brown eggshell color in laying hens. Poultry Science 2016;95:2052-2057.

SAS Institute. SAS users guide. Cary; 2008.

Savegnago RP, Cruz VAR, Ramos SB, Caetano SL, Schmidt GS, Ledur MC, et al. Egg production curve fitting using nonlinear models for selected and nonselected lines of White Leghorn hens. Poultry Science 2012;91 :2977-2987

Sehu A, Kucukersan S, Coskun B, Koksal BH, Citil OB. Effects of dietary glycerol addition on growth performance, carcass traits and fatty acid distribution in cloacal fat in broiler chickens. Revue de Médecine Vétérinaire 2012;163(4):194-200.

Silva VO, Lopes E, Andrade EF, Sousa RV, Zangeronimo MG, Pereira LJ. Uso de co-productosdel biodiesel (Glicerol) como fuentes alternativas de energia em la alimentación animal:uma revisão sistemática. Archivos de Medicina Veterinaria 2014;46:111-120

Suchy P, Strakova E, Kroupa L, Herzig I. The effect of replacing soybean oil with glycerol in feeding mixtures designed for utility layers on their production and state of health. Archiv für Tierzucht 2012;2:184-193.

Sujatha T, Rajini R, Prabakaranc R. Efficacy of pre-lay diet. Journal of Applied Animal Research 2014;42(1):57-64.
Sujatha T, Rajini R. Transitional pullet feed and its significance at sexual maturity. Indian Journal of Animal Research 2015;49(1):77-80.

Summers JD. Influence of prelay treatment and dietary protein level on the reproductive performance of white leghorn hens. Poultry Science $1993 ; 72: 1705-1713$

Swiatkiewicz S, Kolereski J. Effect of crude glycerin level in the diet of laying hens on egg performance and nutrient utilization. Poultry Science 2009;88:615-619.

Van Krimpen Dr MM, Kwakkel RP, André G, van der Peet-Schwering CMC, den Hartog LA, Verstegen MWA. Effect of nutrient dilution on feed intake, eating time and performance of hens in early lay. British Poultry Science 2007;48(4):389-398.

Veldkamp T, Kwakkel RP, Ferket PR, Verstegen MWA. Growth response to dietary energy and lysine at high and low ambient temperature in male turkeys. Poultry Science 2005;84:273-282.

Vongsamphanh P, Preston TR, Leng RA. Glycerol supplementation increased growth rates, decreased the acetate:propionate ratio in rumen VFA, and reduced enteric methane emissions, in cattle fattened on cassava pulp-urea, brewers' grains and rice straw. Livestock Research for Rural Development 2017;29:36.

Yalçın S, Erol H, Özsoy B, Onbaşılar I, Yalçın S, Üner A. Effects of glycerol on performance, egg traits, some blood parameters and antibody production to SRBC of laying hens. Livestock Science 2010;129:129134.

Yang F, Hanna M, Sun R. Value-added uses for crude glycerol-a byproduct of biodiesel production. Biotechnology for Biofuels 2012;5:1-10.

Zheng YW, Zhao LH, Wei YM, Ma QG, Ji C, Zhang Y. Effects of main cereal type and feed form on production performance, egg quality and egg sanitary indices of laying hens. British Poultry Science 2020;1-5.

Zerjal T, Gourichon D, Rivet B, Bordas A. Performance comparison of laying hens segregating for the frizzle gene under thermoneutral and high ambient temperatures. Poultry Science 2013;92:1474-1485. 
